\title{
ASSESSMENT OF GROUND WATER POLLUTION IN PARKING AREAS
}

\author{
Janina Piekutin ${ }^{1}$ \\ 1 Bialystok University of Technology, 45A Wiejska Str., 15-351 Bialystok, Poland, e-mail: j.piekutin@pb.edu.pl
}

Received: 2014.08 .28

Accepted: 2014.10.17

Published: 2015.01 .02

\begin{abstract}
Creation of rain sewer is connected with dehydration of roads and coexisting objects. The paper presents a discussion upon the issue of groundwater contamination by petroleum compounds and other pollutants from transport based on studies of groundwater within the parking lots. The study included 9 parking areas, including 7 in Bialystok, 1 in a residential area outside of Bialystok in Ignatki, and one in Kleosin. The tested waters were subject to determination of COD, total suspension, and petroleum substances expressed as a mineral oil index. The studies have shown that the concentrations of determined parameters were in most cases proportional to the larger runoffs and concentration of petroleum compounds increased with the increase of suspension. It has been shown that from part of the parking lots, the meteoric water was discharged directly into watercourses and exceeds the permissible limits regulated by the Decree.
\end{abstract}

Keywords: meteoric water, parking lots, petroleum substances.

\section{INTRODUCTION}

The continuous development of communication infrastructure is inevitable today. It carries many negative effects [Barański, Gworek 2004]. The aquatic environment and groundwater are especially exposed for such a change. There are many adverse effects associated with the construction of more and more new roads and accompanying parking lots. In the studied parking areas there are places for parking vehicles. Each of them should have a parking space that would be tailored to its needs. Depending on the type of vehicles and cargo that can be carried by them, there is a different risk of environmental contamination [Łęgosz, Jasiński 2009]. Within the parking areas, primarily meteoric sewage is created, which is the result of transformation of rainfall into the surface runoff or as a result of runoff resulting from snow melting [Aniszewski 1998]. The mixture, which goes to the sewage system or directly into the ground, may have a different composition [Kłodziejczyk 2009]. The quantity and quality of wastewater discharged from the parking lots is not constant. Such a situation is affected by many factors, which may include mainly [Ociepa 2009]: the surface of the parking areas, traffic capacity, methods of surface maintenance and operation, air pollution, season, characteristics of rainfall.

Surface of a parking lot is often covered with setts or asphalt. Green parking lots are also possible. The runoffs from these areas depend on the tightness of the used surface material [Gierak 1995, Kłodziejczyk 2009, Merkisz, Piekarski, Słowik 2006]. Some of them may be well-drained, while others do not have such good properties. It should also be pointed out that the area should be kept clean. During winter, parking lots are cleared, but also sprinkled with chemicals that accelerate snow melting. These runoffs affect the quality of wastewater [Kłodziejczyk 2009, Merkisz, Piekarski, Słowik 2006].

Traffic capacity and the number of parking lots in a given area are also significant facts. First of all, it should be noted that their number varies and depends mainly on the frequency of rainfalls and their intensity. Retention of snow cover and then snow melting is also a cause of increasing pollution load. The snow left on a parking lot contains many harmful compounds [Merkisz, Piekarski, Słowik 2006]. During rapid melting, these contaminants get along with pollutants into the sewage system or directly into the ground or 
waters. Referring the quality of wastewater: its composition also changes in some time [Pawluk, Fronczyk, Garbulewski 2011]. If it rains after a long-term dry period, impurities accumulated on the surface of parking lots are the most intensely leached during the first phase of rainfall [Łęgosz, Jasiński 2009, Sadkowski 1990].

The quality of wastewater discharged from parking areas directly to the soil or water is regulated by the law [Regulation of Ministry of Environment on 26 July 2006] [Gierak 1995].

\section{METHODS}

The study was conducted in two series included 9 parking lots of various usage types - from maneuvering areas within companies through those in the housing estates. The water samples were collected from points in Bialystok, Kleosin, and Osiedle Ignatki:

- I sampling point - water sample was collected from the ditch near the park at Wierzbowa Street in Białystok near Entertainment Club "Kraqg". The area includes the parking lot for clients as well as go-cart track. The parking lot has no drainage system, sewage from the runoff directly gets into the ground and then to groundwater.

- II sampling point - at Wierzbowej Street. The parking lot belongs to the car workshop and vehicle inspection station. The parking lot is paved with setts. Sewage from the parking area is discharged to the wastewater system through inlets and wells. Runoffs from this and previously described point get into the Biała river.

- III sampling point - at Pogodna Street. The secure parking lot is within the sampling point. It is designed for cars and includes about 50 parking spaces. It has no setts. Only the staging places are lined with cobblestones. Polluted water remaining after the rainfall can be found in some places. There are 156 covered garages in the south side. Their surface is covered with gravel, not paved and has no drainage. Wastewater flow down through the concrete surface drainage directly into a ditch, from which water was collected.

- IV sampling point - near the maneuver area that is used to teach applicants for car driving license. This place has asphalt and cobblestones. The parking lot has no drainage sys- tem. The wastewater discharge is carried out directly into the sewer drain.

- V sampling point - is located south of the plant "KAN" in Kleosin. In the area of the industrial plant, there is a car park designed primarily for employees and for trucks coming for manufactured products. The drainage is in a form of grooves.

- VI sampling point - is located in a residential housing Ignatki outside the city of Bialystok. The water was collected in the vicinity of the parking lot near the blocks of flats. There are drains in the parking lot. The land slope is in the direction of the test ditch. The test flow is connected to an inlet that supplies the runoff from the parking lot.

- VII sampling point - near the parking of trucks owned by a transportation company. The parking lot is located on the property, through which the ditch flows. The plants and seedlings selling business is carried out within this property. Water from the ditch is used for watering them. At this point, there is also a valve for water stacking.

- VIII sampling point - neighborhood of the property with two parking lots in Hetmańska Street. One is paved with setts, while the second with plates. In the majority, the drainage is in a form of grooves and wells.

- IX sampling point - near the car park of KFC and a petrol station at John Paul II Aleey. Both of these objects have drainage systems. At the petrol station, it is the line drainage with separators for petroleum substances and wells.

Water samples were subject to determination of COD, total suspension, and petroleum compounds expressed as mineral oil index. The analyses were made in accordance with the available methods of investigation. For determination of petroleum compounds, the method using a gas chromatograph was applied. After approximately 4-week intervals, studies were repeated for each of nine sampling points.

\section{RESULTS AND DISCUSSION}

The first collection for the first 3 points occurred during a considerable amount of residual layer of snow. Studies were repeated at the same locations after 4 weeks. In the subsequent three points, samples were also collected when the 


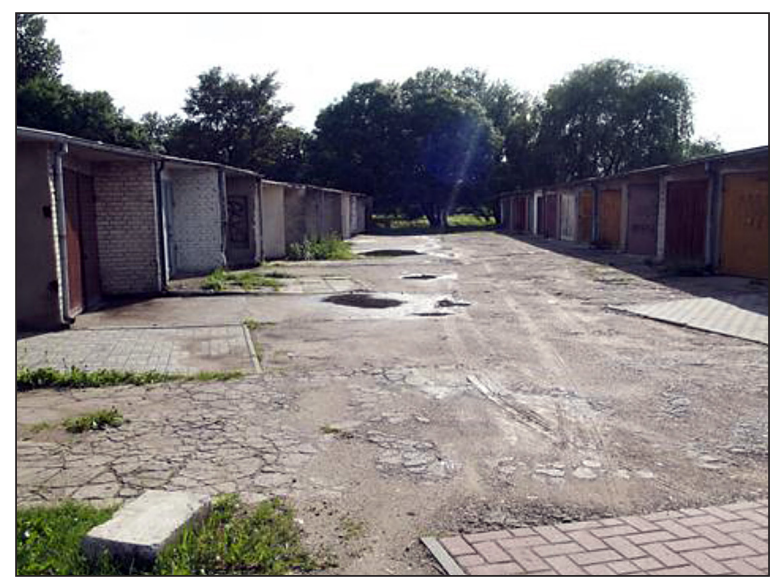

Figure 1. Residual water at the garages in the vicinity of III sampling point

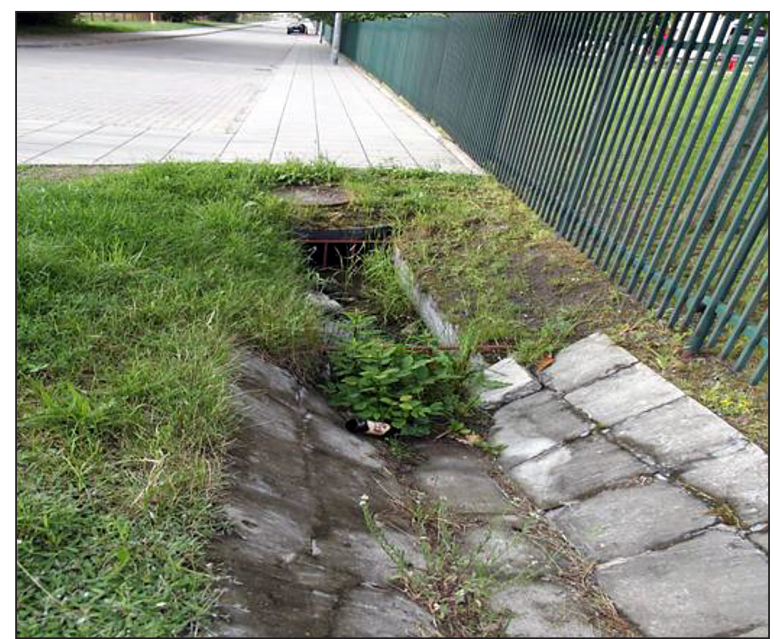

Figure 3. Wastewater discharge into the sewer drain (IV sampling point)

snow cover was still present on the soil layer, while repeating the tests after 4 weeks during the thaw. Samples marked as 7 to 9 were obtained when a layer of snow was already low. Studies were repeated after 4 weeks when there was no snow, and there was no rainfall for a long time.

The highest value of COD (Table 1) was recorded during the collection at the point No 2, where it amounted to $1500 \mathrm{mg} \mathrm{O} / \mathrm{dm}^{3}$ and at point No 3 with $732 \mathrm{mg} \mathrm{O} / \mathrm{dm}^{3}$. When the measurements were repeated, COD values decreased or increased for some points, which could be due to uneven penetration of additional organic pollutants into the waters. The lowest values occurred during the second sampling at points 7,8, and 9. Rain did not occur then for a long time, which could indicate a lesser contamination along with runoff. For the points No 5 and 6, the atmospheric conditions were different, which resulted in uneven penetration of contaminants into the groundwater.

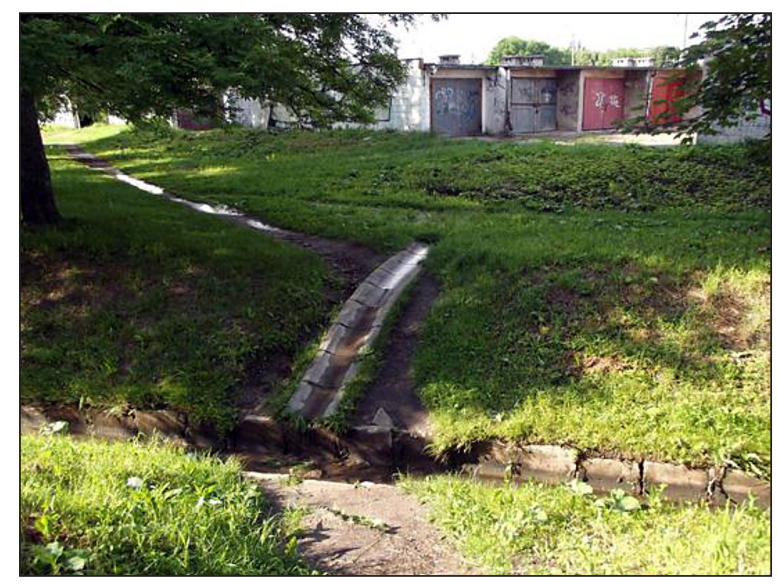

Figure 2. Wastewater discharge from garages area into the studied receiver (III sampling point)

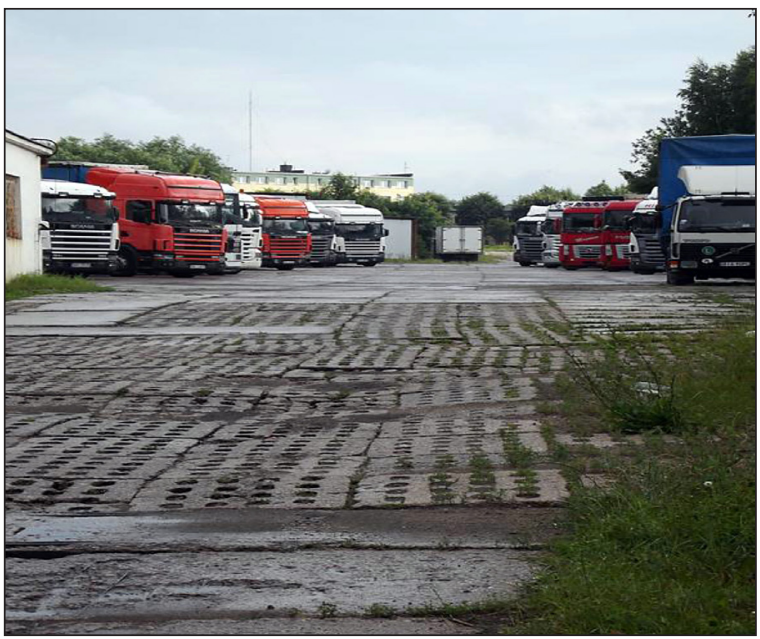

Figure 4. Parking lot near the VII sampling point

At the first sampling point, the suspension at the beginning was $102 \mathrm{mg} / \mathrm{dm}^{3}$, but when measurements were performed after a certain time, the contents decreased to $80 \mathrm{mg} / \mathrm{dm}^{3}$. Additionally, it can be seen that the COD content is high as the amount of petroleum substances at point No 1. Along with the reduction of suspension content, the amount of petroleum derivatives also decreased. Similar changes can be observed in two consecutive samples. In these cases, more suspension can be recorded during the snow cover and snowfall. Whereas, it was less during subsequent sampling at the same points, when a thaw occurred. The dependence of COD and content of petroleum substances on a suspension is also similar.

The opposite situation can be observed during the following sample collection for the next two samples. During the sampling at point No 4, the suspension was only $38 \mathrm{mg} / \mathrm{dm}^{3}$ with a growth to 
Table 1. Total suspension and $\mathrm{COD}_{\mathrm{Cr}}$ in studied samples

\begin{tabular}{|c|c|c|}
\hline $\begin{array}{c}\text { Place of taking } \\
\text { sample }\end{array}$ & $\begin{array}{c}\text { COD } \\
{\left[\mathrm{mg} \mathrm{O}_{2} / \mathrm{dm}^{3}\right]}\end{array}$ & $\begin{array}{c}\text { Suspension } \\
{\left[\mathrm{mg} / \mathrm{dm}^{3}\right]}\end{array}$ \\
\hline I & $106.5^{\mathrm{a}} / 337^{\mathrm{b}}$ & $102 / 80$ \\
\hline II & $1500 / 590$ & $310 / 260$ \\
\hline III & $732 / 365$ & $168 / 160$ \\
\hline IV & $417 / 660$ & $38 / 209$ \\
\hline V & $593 / 396$ & $108 / 88$ \\
\hline VI & $349 / 489$ & $56 / 62$ \\
\hline VII & $304 / 106$ & $10 / 34$ \\
\hline VIII & $301 / 58$ & $23 / 10$ \\
\hline IX & $315 / 62$ & $41 / 10$ \\
\hline
\end{tabular}

Descriptions: a - value for the first sampling, $\mathrm{b}$ - value for the second sampling

$209 \mathrm{mg} / \mathrm{dm}^{3}$ during the following measurement. The content of COD and petroleum compounds at point No 4 was less, but when studies were repeated after some time, the levels of remaining indicators increased along with the increase of the suspension amount. A similar situation is for point No 6, although the suspension differed by only $6 \mathrm{mg} / \mathrm{dm}^{3}$, which is not such a significant difference (Table 1). As it can be seen, the sum of total suspension is very different for different points. Composition of wastewaters from runoffs is very diverse and it is difficult to determine their typical composition. There is no certain uniformity of wastewater discharge as it is in the case of domestic sewage. Filtering the samples, even though they seemed to be quite transparent, the suspension remained on all filters. This means that a fine and hardly falling suspension made up a large part.

The studies also included determinations of petroleum substances that have been converted into a mineral oil index. These substances are very well sorbed by previously discussed suspension [Rychliński 2006, Surygała 2000, Szymański 1995]. According to some data, this value is as high as $82-99 \%$. Floating colored patches of gasoline prove a very close contamination of the aquatic environment [Pawluk, Fronczyk, Garbulewski 2011]. Many of these, however, is dissolved in water and is able to move a considerable distances, and therefore it is difficult to univocally determine the source of such contamination. According to the Regulation of Minister of Environment of 9 November 2011 concerning the quality of surface waters, water in which the petroleum compounds do not exceed $0.2 \mathrm{mg} / \mathrm{l}$ are qualified as class I and II.

The data are presented graphically in charts comparing the first and repeated tests at the same sampling points at different times.

The amount of petroleum substances during the first measurement at point No 1 is much larger and amounts to $60.085 \mathrm{mg} / \mathrm{dm}^{3}$. Studies were conducted when there was a plenty of snow, and the temperature was negative. During the second collection, the value declined to $14.969 \mathrm{mg} / \mathrm{dm}^{3}$ (Figure 5). During the first sampling, considerable snow cover was present at point No 2. During the first sampling, there was a thaw. In this case, during the first collection test, the content of petroleum substances was higher amounting to $49.890 \mathrm{mg} / \mathrm{dm}^{3}$. During the second sampling, this quantity slightly decreased to 42.518 $\mathrm{mg} / \mathrm{dm}^{3}$ (Figure 5). The determined quantity of petroleum substances at point No 3 was 60.722 $\mathrm{mg} / \mathrm{dm}^{3}$ and it increased to $103.239 \mathrm{mg} / \mathrm{dm}^{3}$ after some time (Figure 5). During the sampling at point No 4, the snow cover still remained, yet it was less than during the sample collection for

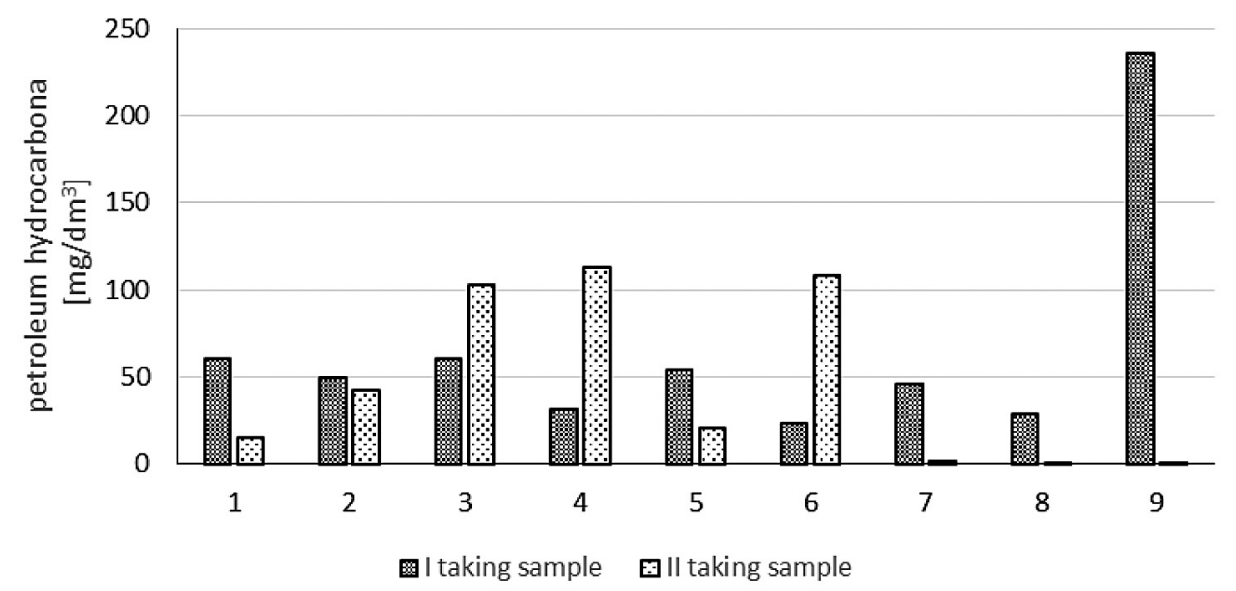

Figure 5. Amounts of petroleum substances at studied sampling points during the first and second sampling 
the points No 1-3, and the concentration was $31.206 \mathrm{mg} / \mathrm{dm}^{3}$. The second sampling at point No 4 was made, when it was raining for a long time; this result was higher more than three and a half times and amounted to $112.506 \mathrm{mg} / \mathrm{dm}^{3}$ (Figure 5). For the collection at point No 5, values in the first case amounted to $53.664 \mathrm{mg} / \mathrm{dm}^{3}$, while measurements repeated after a few weeks revealed decreased level to $20.280 \mathrm{mg} / \mathrm{dm}^{3}$ (Figure 5). Taking into account the melt and rainfall during second sampling at this point, it was to be expected that the results would be significantly higher. The area, on which the test flow is situated, is periodically flooded by sewage from runoff from residential apartment blocks localized behind the railway embankment.

Like in the above two cases, samples were collected during the same collections in similar weather conditions. For sample No 6 (Figure 5), content of petroleum substances was determined for $23.280 \mathrm{mg} / \mathrm{dm}^{3}$, but after a few weeks, this level increased almost five-fold to a value of up to $108.307 \mathrm{mg} / \mathrm{dm}^{3}$. Such a situation could be caused by the thaw and rain. In addition, one inlet probably collecting rainwater, is mounted to the test flow. During the sampling at point No 7, only in some places snow occurred. However, during the collection of the second sample, weather conditions significantly changed. It is illustrated in the above plot (Figure 5). There was no rain for a long time, and snow cover completely disappeared. For point No 7, content of petroleum compounds was $45.836 \mathrm{mg} / \mathrm{dm}^{3}$, while examining the water at the same sampling point, this amount was only $1.627 \mathrm{mg} / \mathrm{dm}^{3}$. During thaws, the quantity of petroleum substances increased, while during the dry period, it significantly decreased. The conditions, under which the samples were collected, were similar to those discussed for point No 7 . The value of petroleum compounds for point No 8 amounted to $29.177 \mathrm{mg} / \mathrm{dm}^{3}$, but after a few weeks, this level decreased to just $0.444 \mathrm{mg} / \mathrm{dm}^{3}$. This parking area is equipped with drains, so a considerable amount of wastewater is drained out of it. During the sampling discussed in the plot (Figure 5), weather conditions were similar to those in the two previous cases. For sample No 9, petroleum compounds content was $236.014 \mathrm{mg} /$ $\mathrm{dm}^{3}$, and during the subsequent collection at the same point, this quantity was determined only for $0.393 \mathrm{mg} / \mathrm{dm}^{3}$. The sampling point was located near the John Paul II Avenue near KFC and gas station. During thaws, petroleum substances were washed away from the gas station. A sudden increase in the amount of rainwater disabled the separators of petroleum substances. The concentrations determined during the subsequent study decreased significantly, which could be due to a lack of rainfall.

\section{CONCLUSIONS}

1. During the surface runoff due to thaw or rainfall, an increase in petroleum substances and suspension contents takes place.

2. Vicinity of high-traffic roads affects the elevation of petroleum substances concentration.

3. Increased amount of suspension causes an increase in petroleum compounds content in the studied flows.

\section{REFERENCES}

1. Aniszewski A. 1998. Rozprzestrzenianie i adsorpcja zanieczyszczeń w płynącej wodzie gruntowej. Wydawnictwo Uczelniane Politechniki Szczecińskiej, Szczecin.

2. Barański A., Gworek B. 2004. Ocena ryzyka zdrowotnego i środowiskowego pochodzącego od gruntów zanieczyszczonych produktami naftowymi. Instytut Ochrony Środowiska, Warszawa.

3. Gierak A. 1995. Zagrożenie środowiska produktami ropopochodnymi.

4. Kłodziejczyk U. et al. 2009. Ekologiczne zagadnienia odwodnienia pasa drogowego. Warszawa.

5. Kościelniak S. et al. 1994. Wskazówki metodyczne do oceny stopnia zanieczyszczenia gruntów i wód podziemnych produktami ropopochodnymi i innymi substancjami chemicznymi w procesach rekultywacji. Wydawnictwo TRIO, Warszawa.

6. Krajewski I. 2000. Metoda oceny zagrożenia jakości wód podziemnych przy pomocy systemu Drastic. Inżynieria Środowiska XI nr 385, Zeszyty Naukowe Akademii Rolniczej we Wrocławiu, Wrocław.

7. Łęgosz A., Jasiński W. 2009. Zalecenia projektowania, budowy i utrzymania odwodnienia parkingów i MOP. Warszawa.

8. Merkisz J., Piekarski W., Słowik T. 2006. Motoryzacyjne zanieczyszczenia środowiska. Wydawnictwo Akademii Rolniczej w Lublinie, Lublin.

9. Mizerski W. 2009. Geologia dynamiczna. Wydawnictwo Naukowe PWN, Warszawa.

10. Osmulska-Mróz B., Sadkowski K. 1990. Zasady ochrony środowiska $\mathrm{w}$ projektowaniu, budowie $\mathrm{i}$ 
utrzymaniu dróg. Dział 07 - ochrona wód w otoczeniu dróg. Warszawa.

11. Pieutin J. 2013. Oczyszczanie wód opadowych z substancji ropopochodnych. Ekonomia i Środowisko, 4, 60-66.

12. Pawluk K., Fronczyk J., Garbulewski K. Wpływ wód spływowych i roztopowych $\mathrm{z}$ infrastruktury drogowej na jakość środowiska gruntowo - wodnego na terenie aglomeracji warszawskiej,
Materiały konferencyjne, Warszawa 2011.

13. Rychliński S. (Ed.) 2006. Metody usuwania zanieczyszczeń węglowodorowych ze środowiska gruntowo-wodnego. AGH, Kraków.

14. Surygała J. 2000. Zanieczyszczenia naftowe w gruncie. Oficyna Wydawn. Politechniki Wrocławskiej.

15. Szymański K. 1995. Ocena zanieczyszczeń wód podziemnych. Wyższa Szkoła Inżynierska w Koszalinie. 